EUROPA REGIONUM TOM XXIII ROK 2015

DOI: $10.18276 / \mathrm{er} .2015 .23-12$

\author{
SZCZEPAN KALINOWSKI, GRZEGORZ GODLEWSKI \\ Akademia Wychowania Fizycznego J. Piłsudskiego w Warszawie, \\ Filia w Białej Podlaskiej
}

\title{
Potencjał turystyczno-rekreacyjny krajobrazu Polesia Zachodniego
}

\section{Wprowadzenie}

$\mathrm{K}_{\mathrm{r}}^{\mathrm{r}}$ rajobrazy są syntezą wszystkich przyrodniczych i kulturowych zjawisk. Krajobraz kulturowy jest przestrzenią, w której materialna i duchowa działalność ludzi nałożyła się na krajobraz naturalny. Krajobraz przyrodniczy podlega stałym i epizodycznym przemianom. Kiedy na zmiany naturalne nakładają się przemiany społeczno-gospodarcze, następuje wyraźne przyspieszenie transformacji krajobrazu. Główne czynniki działalności człowieka wpływające na zmiany walorów przyrodniczych Polesia to przemysł (wydobycie węgla), rolnictwo, melioracja i zagospodarowanie turystyczne.

Polityka przestrzenna musi pogodzić sprzeczność interesów górnictwa, rolnictwa i rekreacji oraz turystki przede wszystkim w południowej części Polesia, gdzie gospodarka wodą na tym obszarze jest najtrudniejszym do rozwiązania problem regionu. Konieczna jest polityka ochrony walorów przyrodniczych Polesia i konieczność umiarkowanego zagospodarowania dla potrzeb rekreacji i turystyki. Ograniczenie niekorzystnych zmian może zapewnić polityka zrównoważonego rozwoju.

Celem opracowania jest określenie użyteczności potencjału krajobrazu Polesia Zachodniego na potrzeby turystyki i rekreacji. Zastosowana przez autorów metoda to przede wszystkim analiza literatury i dokumentów oraz obserwacja własna obiektów podczas licznych podróży (jeden z autorów jest wieloletnim przewodnikiem). Duża różnorodność walorów stanowi o potencjale umożliwiającym rozwój wielu rodzajów turystyki, m. in.: poznawczej, wypoczynkowej i kwalifikowanej. 


\section{Poleski krajobraz}

Polesie - kraina geograficzna i historyczna, leżąca głównie na terytorium obecnej Białorusi i Ukrainy oraz częściowo Polski - Polesie Zachodnie (Polesie Podlaskie, Polesie Lubelskie). Rzadziej jest używana nazwa Polesie Nadbużańskie. Stanowi południowo-zachodnią część Niżu Wschodnioeuropejskiego. Krajobraz tego obszaru to przede wszystkim zabagnione równiny. Polesie Zachodnie stanowi północno-zachodnią część Polesia, w lewym dorzeczu Bugu. Część polska zajmuje ok. 4,7 tys. $\mathrm{km}^{2}$. Pod względem krajobrazowym są to płaskie równiny denudacyjne i wodno-akumulacyjne, częściowo zabagnione, związane z utrudnionym odpływem, z dużym udziałem torfowisk. Pod względem geologicznym należy do platformy prekambryjskiej - na północy skały prekambru są przykryte utworami jury, kredy i kenozoiku, na południu utworami paleozoiku, z karbońskimi złożami węgla kamiennego (Lubelskie Zagłębie Węglowe). Występowanie na powierzchni lub na małych głębokościach rozpoznanych margli wieku kredowego przyczyniło się do rozwoju na Polesiu Zachodnim zjawisk krasowych.

Polesie Wołyńskie w granicach Polski położone jest w lewym dorzeczu Bugu, to lekko pofalowana równina między Polesiem Zachodnim na północy, Wyżyną Lubelską na zachodzie i południu. Wśród bagiennych równin wznoszą się garby zbudowane z margli kredowych i piaskowców trzeciorzędowych, często o znacznych wysokościach (najwyższe między Rejowcem Fabrycznym a Chełmem, 240-260 m). W granicach Polski wyróżnia się na Polesiu Wołyńskim 3 mniejsze jednostki fizycznogeograficzne: Obniżenie Dorohuckie i Dubieńskie oraz Pagóry Chełmskie (Kondracki 2002).

Cechą charakterystyczną krajobrazu poleskiego są: monotonia rzeźby terenu, niewielkie różnice wysokości, płytkie występowanie wód gruntowych, liczne torfowiska, moczary i bagna. Jedynym urozmaiceniem są garby i pagóry morenowe z okresu zlodowacenia środkowopolskiego. Wody gruntowe zalegające tuż pod powierzchnią tworzą płytkie jeziora i rozległe bagna. Na terenie Polesia występują liczne rzeki. Blisko połowę powierzchni zajmują bagna i związane z nimi kompleksy torfowisk.

Jezior jest 61, największe Uściwierz ma 300 ha, najgłębsze Piaseczno - $39 \mathrm{~m}$. Jez. Wytyckie zostało zamienione na zbiornik retencyjny i powiększone do 487 ha. Jeziora odznaczają się mało urozmaiconym kształtem, a tym samym mają słabo rozwiniętą linię brzegową. Większość z nich silnie zarasta. Charakterystyczny dla wielu jest przybrzeżny kożuch roślin pływających (zwany spleją), utrudniający rekreacyjne wykorzystanie (Harasimiuk, Michalczyk et al. 1998). 
Powstanie torfowisk związane jest $\mathrm{z}$ zarastaniem zbiorników wodnych, głównie jezior. W wyniku melioracji, przede wszystkim w latach pięćdziesiątych XX w., zostały zagospodarowane rolniczo jako użytki zielone. Ogółem torfowisk ponad 1 ha jest 1743, a ich powierzchnia wynosi 133 tys. ha. Największe $\mathrm{z}$ nich to Krowie Bagno i Bagno Bieleckie (Borowiec 1990).

Tereny zalesione zajmują ok. $30 \%$ powierzchni Polesia. Lasy nie stanowią tu zwartej strefy, ale raczej występują w mniejszych kompleksach. W lasach włodawskich i sobiborskich króluje sosna, z domieszką dębu, grabu, brzozy, osiki, a w miejscach mokrych - olszy czarnej. Lasy o gęstym poszyciu, w miejscach suchych iglaste, a nad rzekami przeważają liściaste krzaki. Roślinność obfituje w relikty glacjalne (wierzba lapońska, brzoza niska) oraz bagienne lasy łęgowe i olsy (z olszą czarną). Na terenach wyżej wzniesionych występują bory sosnowe i lasy mieszane.

\section{Zmiany w krajobrazie pod wpływem działalności człowieka}

Wskutek działalności człowieka krajobraz został zdewastowany, przede wszystkim w okolicach kopalni Bogdanka, na większości obszaru Polesia zachował jednak cechy krajobrazu naturalnego. Wody niemal wszystkich rzek są silnie zanieczyszczone, do czego przyczyniają się też zmywy z pól i ścieki wiejskie. Lasy uległy znacznemu przetrzebieniu. Włodawa oraz inne większe miasta są położone na obrzeżach regionu i spełniają ważną rolę logistyczną w obsłudze turystów: Biała Podlaska, Terespol, Międzyrzec Podlaski, Łęczna, Ostrów Lubelski, Radzyń Podlaski, Parczew i Chełm.

Przemysł jest uciążliwy dla środowiska, np. garbarnia we Włodawie, żwirownia w Międzyrzecu Podlaski, huta szkła w Parczewie, cementownie w Chełmie i Rejowcu. Olbrzymie cementownie powoduja zapylenie powietrza, które przemieszcza się na obszar Polesia, a nadmierny pobór wód podziemnych zaburza stosunki wodne. Pas skał karbońskich z węglem kamiennym ciagnie się od okolic Hrubieszowa po okolice Radzynia Podlaskiego. Na tym obszarze występują surowce skalne: węglanowe wapienie, opoki i margle, surowce ilaste ceramiki budowlanej oraz surowce okruchowe: piaski szklarskie, formierskie, silikatowe, budowlane i drogowe. Na terenie Lubelskiego Zagłębia Węglowego wydzielono 11 pól górniczych. Na wschód od Łęcznej powstała kopalnia w Bogdance w 1982 r., która stanowi znaczne zagrożenie przyrody, powodując powstanie wokół kopalni leja depresyjnego wód podziemnych, zwałowanie skał dołowych zawierających ciężkie meta- 
le, szkodliwe oddziaływanie wzmożonego transportu samochodowego, znaczne zanieczyszczenie powietrza. Kopalnia realizuje program zagospodarowania odpadów skalnych powstających przy wydobywaniu wegla. Część tego materiału wykorzystywana jest do produkcji cegły klinkierowej (Borchulski 1996).

Rolnictwo degraduje środowisko przez stosowanie środków chemicznych. Gospodarstwa są rozdrobnione, a krajobraz do niedawna typowy na Polesiu pasmowy układ pól, rozdzielony wyraźnymi miedzami, jest już unikalny w skali krajobrazów świata (Wojciechowski 2000; Richling, Solon 1996). Prace melioracyjne stanowią znaczne zagrożenie, już zniszczyły górne dorzecza Tyśmienicy i Piwonii. Kanał Wieprz-Krzna (dalej Kanał W-K) o dł. 142 km, był budowany w latach 1954-1961. Celem było stworzenie systemu melioracyjnego i uaktywnienie gospodarki rolniczej na obszarze ponad 5 tys. $\mathrm{km}^{2}$. Kanał spowodował poważne zmiany w środowisku. Przyrodnicy bezskutecznie proponowali, aby region jezior wyłączyć spod wpływu kanału. Dopływ zanieczyszczonej wody z Wieprza o dużym stopniu mineralizacji powoduje eutrofizację jezior i torfowisk, co prowadzi do znacznych przekształceń biocenoz. Jeziora Dratów i Mytycze są obecnie zbiornikami retencyjnymi, obwałowanymi i napełnianymi grawitacyjnie wodą z kanału. Powstały nowe zbiorniki: Zahajki, Mosty, Opole, Żelizna oraz Krzczeń. Wzdłuż kanału zaczął się szybko zmniejszać zasięg mokradeł i bagien, a łąki często stawały się suchymi nieużytkami.

Bug jest jedną z nielicznych rzek tej wielkości w Europie, która na całym odcinku granicznym jest nieuregulowana, bieg jego jest kręty, licznie wystęują starorzecza zwane bużyskami. Graniczne położenie Bugu spowodowało, że nie były na nim prowadzone prace melioracyjne. Zachowały się nad nim lasy łęgowe i żyzne łąki. Dolina Bugu jest korytarzem ekologicznym o znaczeniu europejskim. Nad brzegami rzeki znajdują się 3 Parki Krajobrazowe. Wody na całej długości są zanieczyszczone. Obecnie największym zagrożeniem dla doliny Bugu jest zrzut ścieków do rzeki oraz zabudowa brzegów, a także próby obwałowania (Wojciechowski 2003; Kalinowski 2005).

Z małymi wyjątkami, doliny rzek na Polesiu są płaskie, szerokość ich wynosi $1-2 \mathrm{~km}$, pokrywają je torfowiska głębokie lub też łąki mniej lub więcej zabagnione. Do Świnki między Puchaczowem i Cycowem zrzucane są w dwóch miejscach wody dołowe i ścieki z kopalni „Bogdanka” (ok. 100 1/s). Podczas budowy Kanału W-K, Tyśmienicę przerzucono do nowego koryta omijającego zbiornik Krzczeń, a rowy sięgają do Bagien Niedźwiedzkich położonych na południe od jeziora Rogoźno. System rowów łączy też rzekę z jeziorem Dratów, 
które zostało zamienione na zbiornik. W okolicach Uścimowa Piwonia Południowa zasila duży kompleks stawów, a jej dopływ Bobrówka odprowadza wody z jez. Zagłębocze, przepływa syfonem pod Kanałem W-K i omija zamienione na zbiornik retencyjny jez. Domaszne. Niemal wszystkie rzeki w dorzeczu Uherki zostały uregulowane na całej długości, wykonano też wiele rowów, gdzie sieć wodna należy obecnie do najgęstszych na Polesiu.

O atrakcyjności przyrodniczej i krajobrazowej Polesia decydują przede wszystkim stosunki wodne. Ten z pozoru obszar nadmiarów wody, w rzeczywistości cechuje się wysokimi deficytami wody. Występujące na tym terenie okresowe nadmiary bądź braki wody skłoniły użytkowników do podejmowania licznych prób regulowania stosunków wodnych, czego efektem stało się znaczne przyśpieszenie naturalnego, powolnego tempa obiegu wód. Obecnie konieczne jest prowadzenie działań o charakterze renaturalizacyjnym w celu spowolnienia tempa odpływu wód z terenu i przywrócenia naturalnej retencji.

\section{Krajobraz kulturowy}

Bogactwo kulturowe trzech religii i kultur, które współistniały na terenie Polesia: polskiej katolickiej, unicko-prawosławnej i żydowskiej przypomina do dziś tradycje tolerancji Rzeczpospolitej. Elementami ożywiającymi równinny krajobraz poleski są liczne kapliczki i krzyże przydrożne, częściowo zniszczone w okresie PRL. Po społeczności żydowskiej zostały nieliczne kirkuty i synagogi w Łęcznej i Włodawie. Poleski orient to dwa mizary (cmentarze tatarskie) w Studziance i Zastawku.

Na Polesiu są liczne cerkwie prawosławne, m.in. we Włodawie, Horostycie, Sosnowicy, Uhrusku oraz monastyr z cerkwią z św. Onufrego w Jabłecznej. Odpust św. Onufrego 24 czerwca przyciaga rzesze pielgrzymów. Na pątniczym szlaku najwięcej pielgrzymów przyciagają sanktuaria katolickie w Chełmie, Kodniu, Orchówku, Parczewie oraz wyjątkowe w skali kraju neounickie Kostomłoty. Dużą wartość artystyczną mają barokowe kościoły p.w. św. Ludwika we Włodawie, p.w. Rozesłania Apostołów w Chełmie oraz renesansowa świątynia z XVII w. w Łęcznej.

Architektura drewniana szybko znika z krajobrazu Polesia, próbują ją ocalić właściciele prywatnych skansenów w Holi i w Kołaczach (Zagroda Poleska). Najcenniejsze drewniane świątynie znajdują się w miejscowościach: Hanna, Kodeniec, Kościeniewicze, Ortel Królewski i Wereszczyn. Po dawnych właścicielach ziemskich zostały nieliczne pałace i dwory: Adampol, Dorohusk, Horo- 
dyszcze, Jabłoń, Milanów oraz oficyna z XVIII w. w Sosnowicy związana z T. Kościuszką. Pozostałości fortyfikacji rosyjskich z XIX i XX w. znajdują się w okolicy Terespola. Rzadko spotykanym rozwiązaniem urbanistycznym jest „czworobok” z XVIII w. we Włodawie. W tym miejscu H. Sienkiewicz umieścił pojedynek Wołodyjowskiego z Kmicicem (Kalinowski 1993).

Muzea znajdują się w miejscowościach: Biała Podlaska, Chełm, Kodeń, Łęczna Romanów, Włodawa, Załucze Stare, a galerie: Biała Podl., Chełm, Janów Podl., Międzyrzec Podlaski i Parczew. Żywe są ośrodki sztuki ludowej, np. w Dołhobrodach, Woli Uhruskiej. Najważniejsze Miejsca Pamięci Narodowej związane są z powstaniem 1863, wojną w 1792 i 1920 oraz II wojną światową, w tym Muzeum Byłego Obozu Zagłady w Sobiborze (Kalinowski 2004).

\section{Obszary chronione}

Osuszenie Polesia spowodowało zanik wielu rzadkich gatunków roślin i zubożenie gatunkowe fauny, dlatego też priorytetem jest ochrona środowiska naturalnego. Na obszarze Polesia Zachodniego utworzono Poleski Park Narodowy (dalej PPN), liczne parki krajobrazowe oraz rezerwaty przyrody.

Transgraniczny Rezerwat Biosfery „Polesie Zachodnie” powstał 5 IX 2012 r. Jest to wydarzenie o randze europejskiej, ponieważ to drugi tego typu obiekt w Europie, tym razem na terytorium Polski, Ukrainy i Białorusi i obejmuje ok. 280 tys. ha i jest jednym z większych tego typu obiektów na kontynencie.

W 1990 utworzono Poleski Park Narodowy, którego celem jest ochrona unikatowych zespołów roślinności reliktowej zaliczanych do tundry i lasotundry. Jest to najdalej na południowy zachód wysunięty fragment tego typu roślinności w Europie. Obejmuje liczne bagna, torfowiska i jeziora krasowe oraz naturalne kompleksy leśne z bogactwem flory i fauny, znajdujące się na Równinie Łęczyńsko-Włodawskiej. Zachowane w tym rejonie ekosystemy bagienne to obszary, które rozwijały się bez ingerencji człowieka od czasów ustąpienia ostatniego zlodowacenia. Powierzchnia parku wynosi 9764,3071 ha. Jako ważny obszar podmokły chroniony jest przez Konwencję Ramsarską. Prawie cały teren parku zajmują równiny torfowe (Chmielewski 2000).

Jednocześnie z osuszaniem obszarów podmokłych w XX w. rozpoczęła się niekorzystna dla bogactwa przyrodniczego sukcesja roślinności drzewiastej i krzewiastej, torfowiska zaczęły zarastać i przekształcać się w mniej cenne zbiorowiska leśne i zaroślowe. Od kilkunastu lat w PPN prowadzona jest czynna ochrona torfowisk polegająca na ograniczaniu rozwoju roślinności drzewiastej poprzez jej usuwanie (Radwan 2002). 
Formy ochrony przyrody na Polesiu Zachodnim

\begin{tabular}{|l|c|l|}
\hline Rodzaj obiektu & Ilość & \multicolumn{1}{|c|}{ Przykładowe obiekty } \\
\hline MRB UNESCO & 1 & MR Biosfery „Polesie Zachodnie” \\
\hline Park Narodowy & 1 & Poleski Park Narodowy \\
\hline Park Krajobrazowy & 7 & Sobiborski PK, Chełmski PK \\
\hline Obszar Chronionego Krajobrazu & 7 & Poleski, Nadbużański, Chełmski \\
\hline Natura 2000 & 37 & „Krowie Bagno”, „Dolina Środkowego Bugu” \\
\hline Rezerwaty przyrody & 32 & „Żółwiowe Błota”, „Trzy Jeziora” \\
\hline Pomniki przyrody & ok. 700 & Dąb „Bolko” w Hniszowie, Dąb „Miłości” w Leśnej \\
\hline
\end{tabular}

Źródło: opracowanie własne na podstawie literatury przedmiotu.

Poleski Park Narodowy należy do europejskiej sieci ekologicznej NATURA 2000, zarówno jako ostoja siedliskowa (SOO), jak i ostoja ptasia (OSO). Europejska sieć ekologiczna Natura 2000 na Polesiu obejmuje m.in. Krowie Bagno, Ostoję Poleską, Polesie, Lasy Sobiborskie, Bagno Bubnów, Europejski Korytarz Ekologiczny Bugu - Dolina Środkowego Bugu.

\section{Zagospodarowanie turystyczne i obiekty rekreacyjne}

Pojezierze Łęczyńsko-Włodawskie jest terenem wypoczynkowym ważnym dla regionu lubelskiego. Do rekreacyjnego zagospodarowania nadają się najgłębsze jeziora: Zagłębocze, Rogóźno, Piaseczno, Krasne, Bialskie i Białe k/Włodawy. Brzegi ich są przeważnie piaszczyste i tylko wzdłuż niewielkich odcinków rozwija się wodna roślinność zakorzeniona. Od lat 60 . XX w. nad jeziorami postępuje niekontrolowany rozwój budownictwa, który doprowadził do dużych zmian w otoczeniu zbiorników. Także duże nagromadzenie turystów wypoczywających nad jeziorami powoduje degradację ich walorów przyrodniczych (Wilgat 1998).

Infrastruktura turystyczna ułatwia turystom korzystanie $\mathrm{z}$ walorów poleskiego krajobrazu. Noclegi, gastronomia, biura podróży: Biała Podlaska, Chełm, Dorohusk, Dubienka, Kodeń, Krasne, Łęczna, Parczew, Piaseczno, Rogoźno, Sławatycze, Sosnowica, Urszulin, Wola Uhruska, Włodawa-Okuninka; przejścia graniczne: Terespol, Sławatycze, Dorohusk, Zosin; konsulaty: Białorusi w Białej Podlaskiej i Ukrainy w Lublinie, ale turystykę transgraniczną ogranicza brak przejścia we Włodawie.

Przybywa obiektów służących rekreacji. Baseny: Biała Podlaska, Chełm, Łęczna, Międzyrzec Podlaski; kąpieliska i wypożyczalnie sprzętu wodnego: Białka 
k/Parczewa, Chotyłów, Okuninka, jez. Firlej, Krasne, Łukcze, Rotocze; kręgielnie: Biała Podlaska i Chełm; wypożyczalnia rowerów: Urszulin; sztuczne lodowisko Biała Podlaska i Chełm; wyciąg narciarski: Kobylany i Międzyrzec Podlaski; korty tenisowe: Biała Podlaska, Chełm, Chotyłów, Łęczna, Międzyrzec Podlaski, Ostrów Lubelski, Terespol, Włodawa; skate park w Chełmie; kina: Biała Podlaska, Chełm, Łęczna, Międzyrzec Podlaski i Włodawa (Godlewski, Zalech 2010).

Atrakcją znaną nie tylko w regionie są podziemia w Chełmie. Wielu turystów przyciaga pokaz garncarski w Pawłowie oraz imprezy: Festiwal Trzech Kultur we Włodawie, Festiwal Piosenki Dziecięcej w Okunince, Jarmark Holeński, Międzynarodowa Biesiada Nadbużańska w Sławatyczach, Dni Sosnowicy i Biegi Kościuszkowskie, Międzynarodowy Festiwal Rockowy „Chełmstok” $\mathrm{i}$ in.

Potencjał krajobrazu poleskiego umożliwia uprawianie różnych form turystyki i rekreacji. Turystka ekologiczna, dzięki zasobom natury, może się rozwijać w oparciu o gospodarstwa agroturystyczne z regionalną kuchnią, na obszarach chronionych jest możliwość organizowania wycieczek dydaktycznoprzyrodniczych. Turystyka religijna, wykorzystując szlak pątniczy: Chełm, Parczew, Włodawa-Orchówek, Jabłeczna, Kodeń i Kostomłoty, przyciaga rocznie ponad 100 tys. pielgrzymów. Na Polesiu panują dogodne warunki do uprawiania aktywnej turystyki i rekreacji dzięki sieci szlaków. Wędkarstwo, kąpiele i sporty wodne oraz możliwość nurkowania, żeglowania umożliwiają wypożyczalnie sprzętu wodnego przede wszystkim nad jeziorami: Bialskie, Białe, Piaseczno, Krasne, Łukcze i Zagłębocze.

Szlaki turystyczne: w PPN i w otulinie mają łączną długość 109 km, z czego $34 \mathrm{~km}$ znajduje się na terenie Parku. Zostały wytyczone tak, aby umożliwić zwiedzającym poznanie najciekawszych fragmentów Poleskiego Parku Narodowego i obejrzenie jego wyjątkowych walorów przyrodniczych. Wszystkie szlaki tworzą system pozwalający na wielowariantowe projektowanie tras wycieczek zarówno pieszych, jak i rowerowych. Niezwykle istotne z dydaktycznego punktu widzenia jest powiązanie szlaków turystycznych ze ścieżkami przyrodniczymi i Ośrodkiem Dydaktyczno-Muzealnym PPN. Poleski Szlak Konny to profesjonalna trasa jeździecka, jest jednym z najdłuższych w kraju. Kolarze mają do dyspozycji kilka rozwiązań, m.in. Nadbużański Szlak Rowerowy, kajakarze przede wszystkim rzekę Bug i dla początkujących - Włodawkę.

Sześć ścieżek przyrodniczych w PPN ma charakter poznawczy, edukacyjny. Poprowadzone są po najbardziej charakterystycznych i jednocześnie najciekawszych ekosystemach Parku. Wyposażone są w tablice informacyjne, mapy, 
przystanki z opisami, zadaszenia, ogrodzone parkingi, wieże widokowe, a także urządzenia ułatwiające poruszanie się po terenach podmokłych i torfowiskach: drewniane kładki, platformy i mostki.

Aby zapewnić zwiedzającym PPN możliwość obejrzenia zwykle niedostępnych terenów bagiennych, zbudowano 7 wież widokowych. Podziwiać można z nich rozległą panoramę otwartego torfowiska węglanowego Bagno Bubnów, widok na podobne torfowisko Bagno Staw oraz krajobraz torfowiska wysokiego typu kontynentalnego - Durne Bagno.

Tabela 2

Znakowane szlaki turystyczne na Polesiu Zachodnim /wybór/

\begin{tabular}{|l|l|l|r|}
\hline \multicolumn{1}{|c|}{ Nazwa szlaku } & \multicolumn{1}{c|}{ Przebieg szlaku } & \multicolumn{1}{c|}{ Kolor } & \multicolumn{1}{c|}{ Długość } \\
\hline 1. Nadbużański (rowerowy) & Terespol-Hrubieszów & czerwony & ok. $200 \mathrm{~km}$ \\
\hline 2. Pojezierny Północny & Włodawa-jez. Białe-Urszulin & niebieski & $120 \mathrm{~km}$ \\
\hline 3. Pojezierny Południowy & Urszulin-Bagno Bubnów-Hniszów & żółty & ok. $60 \mathrm{~km}$ \\
\hline 4. Poleska Dolina Bugu & Siedliszcze-Różanka & kajakowy & ok. $60 \mathrm{~km}$ \\
\hline 5. Poleski Szlak Konny & Włodawa-Chełm-Sosnowica & biały kwadrat & $280 \mathrm{~km}$ \\
\hline 6. Ścieżki edukacyjne & Polesie Zachodnie & 17 różnych tras & ok. $70 \mathrm{~km}$ \\
\hline
\end{tabular}

Źródło: opracowanie własne na podstawie źródeł kartograficznych.

Obszar Parku stanowią rozległe torfowiska oraz unikatowe formy bagienne, co oznacza dogodne warunki do powstania największego w kraju lęgowiska żółwia błotnego, wpisanego do Polskiej i Europejskiej Czerwonej Księgi Zwierząt jako gatunek narażony na wyginięcie. Bogactwo i unikatowość ornitologiczna w skali europejskiej przyciaga liczne grupy miłośników przyrody z kraju i z zagranicy.

Liczne szlaki turystyczne wiodą przez tereny najbardziej atrakcyjne krajobrazowo i przyrodniczo, prowadząc także do miejscowości, w których znajdują się obiekty zabytkowe i muzealne. Polesie, wychodząc naprzeciw wymogom współczesnego życia, oferuje doskonałe warunki rekreacyjno-turystyczne dla osób poszukujących aktywnego wypoczynku w weekendy (Baranowska-Janota 1998).

Dobrze zagospodarowane są brzegi jezior Rotcze i Rogóźno. Najbardziej intensywnie jest rozbudowana baza noclegowa nad jeziorami Piaseczno, Łukcze, Krasne i Zagłębocze, w efekcie naturalna chłonność turystyczna obszaru została przekroczona ponad dwukrotnie. Obserwuje się wydeptywanie runa leśnego, zaśmiecanie terenu, wrzucanie odpadów i mycie samochodów w jeziorach, hałas, wycinanie drzew na ogniska i in. Koło Włodawy ,perła regionu”, i Jez. Białe otoczone lasami, ma wody o I klasie czystości. W sezonie dziennie przewija się tam ponad 5 tys. 
turystów, a w szczycie sobotnio-niedzielnym około 30 tys. Tylko polityka zrównoważonego rozwoju umożliwi pogodzenie turystyki i rekreacji bez uszczuplenia zasobów przyrodniczych Polesia (Krukowska, Skowronek 2009, Borchulski 2003).

\section{Baza noclegowa}

Baza noclegowa, stanowiąca podstawowy element zagospodarowania turystycznego, na Polesiu Zachodnim charakteryzuje się dużą różnorodnością obiektów. Najlepiej rozbudowana baza noclegowa jest w powiecie bialskim i włodawskim. Skupia się w miastach i nad jeziorem Białym koło Włodawy, które jest najlepiej zagospodarowanym turystycznie akwenem Polesia Zachodniego. Charakterystyczną cechą bazy noclegowej w Okunince nad jez. Białym jest jej sezonowość.

Tabela 3

Baza noclegowa turystyki w powiatach Polesia Zachodniego w 2013 roku

\begin{tabular}{|c|c|c|c|c|c|c|c|}
\hline \multirow[b]{2}{*}{ Powiat } & \multirow[b]{2}{*}{$\frac{\frac{\lambda}{y}}{\frac{0}{0}}$} & \multicolumn{2}{|c|}{ Miejsca noclegowe } & \multicolumn{2}{|c|}{ Korzystający z noclegów } & \multicolumn{2}{|c|}{ Udzielone noclegi } \\
\hline & & $\frac{E}{0}$ & $\begin{array}{c}\text { w tym } \\
\text { całoroczne }\end{array}$ & 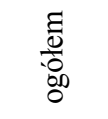 & $\begin{array}{l}\text { w tym turyści } \\
\text { zagraniczni }\end{array}$ & $\frac{\Xi}{0}$ & $\begin{array}{c}\text { w tym } \\
\text { turyści } \\
\text { zagraniczni }\end{array}$ \\
\hline Razem & 102 & 5541 & 1956 & 150512 & 32955 & 265664 & 47219 \\
\hline Biała Podlaska & 31 & 1490 & 896 & 82804 & 25584 & 101370 & 28030 \\
\hline Chełm & 13 & 852 & 619 & 27585 & 6254 & 63505 & 17764 \\
\hline Łęczna & 5 & 271 & 72 & 1552 & 27 & 5474 & 31 \\
\hline Parczew & 10 & 402 & 86 & 4844 & 13 & 13931 & 86 \\
\hline Włodawa & 43 & 2526 & 283 & 33727 & 1077 & 81384 & 1308 \\
\hline
\end{tabular}

Źródło: opracowanie własne na podstawie: Województwo lubelskie, Urząd Statystyczny w Lublinie 2014, s. 263.

W powiecie bialskim połowa miejsc noclegowych znajduje się w Białej Podlaskiej, dużo obiektów noclegowych zlokalizowano w dolinie rzeki Bug. Z obiektów hotelowych skorzystało ponad 82 tys. osób, w tym 25 tys. turystów, przede wszystkim z Białorusi. Zagraniczny ruch turystyczny na Polesiu Zachodnim, poza powiatem bialskim, jest słabo rozwinięty. Powiat włodawski choć ma największą ilość obiektów noclegowych, to nocowało w nich tylko 1077 obcokrajowców (tab. 3).

Duże znaczenie, szczególnie w okresie letnim, ma letnia baza noclegowa o niskim standardzie, którą tworzą: szkolne schroniska młodzieżowe i zespoły domków turystycznych. Odrębnym problemem w regionie jest baza noclegowa o najwyższym poziomie usług, Niewiele jest hoteli o wyższym standarcie.

W powiecie włodawskim baza noclegowa jest skoncentrowana przede wszystkim w Okunince nad jeziorem Białym. Wokół akwenu zlokalizowano dwa hotele 
i 32 ośrodki wypoczynkowe, z który część tylko jest całorocznych, są też pensjonaty, pokoje gościnne, pola campingowe, namiotowe i in. Agroturystyka nad Bugiem najlepiej jest rozwinięta w gm. Wola Uhruska, która dysponuje ok. 100 miejscami noclegowymi z możliwością skosztowania potraw regionalnych.

Najwięcej osób w 2013 r. - 74,1\% gościło w gminie Włodawa. (Bank Danych Lokalnych, www.stat.gov.pl/bdl/) W okolicach jez. Białego od kilkudziesięciu lat jesteśmy świadkami swoistej kolonizacji turystycznej. Nadmierna rozbudowa bazy noclegowej prowadzi do sztucznego kreowania przestrzeni zagrażającej środowisku przyrodniczemu. Władze samorządowe winne analizować skutki zagospodarowania przestrzennego dla środowiska. Obiekty bazy gastronomicznej towarzyszą na ogół obiektom noclegowym, ponadto w większej liczbie występują w miastach, a w sezonie turystycznym w miejscowościach, gdzie przebywa większa liczba turystów, głównie w gminie Włodawa.

\section{Podsumowanie}

1. Zagospodarowanie turystyczne Polesia Zachodniego jest słabe i bardzo nierównomierne.

2. W obszarach o dużych walorach przyrodniczych wskazana jest ostrożność we wprowadzaniu nowych funkcji. Decyzje dotyczące zagospodarowania należy poprzedzać wnikliwymi obserwacjami i badaniami terenowymi. Ośrodki obsługi turystów powinny znajdować się poza obszarami chronionymi.

3. Unikalne walory antropogeniczne Polesia, to przede wszystkim wielokulturowość, która może być szansą na rozwój turystyki kulturowej i edukacyjnej.

4. Polesie cechuje duża różnorodność środowiska naturalnego i cenne zasoby przyrodnicze. Duże możliwości rozwoju ma w regionie turystyka wypoczynkowa i ekologiczna.

5. Liczne szlaki turystyczne i ścieżki edukacyjne umożliwiają rozwój turystyki kwalifikowanej.

6. Mała ilość przejść granicznych jest barierą dla turystyki przygranicznej i tranzytowej.

\section{Bibliografia}

Baranowska-Janota M.: Zasady i modele zagospodarowania rekreacyjnego parków krajobrazowych, w: Problemy tworzenia i zagospodarowania systemu obszarów chronionych w Polsce Środkowowschodniej i na Ukrainie. TWWP. Lublin-Zamość. 1988.

Borchulski Z. Oddziaływanie wydobycia węgla z kopalni Bogdanka na stosunki wodne Pojezierza Lęczyńsko-Włodawskiego, w: Funkcjonowanie ekosystemów wodnobłotnych w obszarach chronionych Polesia. Wydawnictwo UMCS, Lublin. 1996. 
Borchulski Z. (red.). Strategia zrównoważonego rozwoju Polesia Zachodniego 2004-13, Lublin 2003.

Borowiec J., Torfowiska regionu lubelskiego. Warszawa. 1990.

Chmielewski T.J., (red.): Międzynarodowy rezerwat biosfery Polesie Zachodnie: projekt harmonizacji przyrody i kultury. Lublin: Poleski Park Narodowy, Urszulin 2000.

Godlewski G., Zalech M. Ocena potencjału rekreacyjnego wybranych miast Lubelszczyzny w: A. Richling (red.) Krajobrazy rekreacyjne - ksztattowanie, wykorzystanie, transformacja, t. XXVII, Warszawa-Biała Podlaska 2010.

Harasimiuk M., Michalczyk Z., Turczyński M. (red.): Jeziora łęczyńsko-włodawskie: monografia przyrodnicza, Lublin 1998.

Kalinowski S., Walory krajoznawczo-turystyczne Doliny Nadbużańskiej (odcinek graniczny między Polską i Białorusią), Podlaski Kwartalnik Kulturalny, nr 1, 1993.

Kalinowski S., Przewodnik po trasach rowerowych pótnocnej części Euroregionu Bug, Biała Podlaska 2004.

Kalinowski S., Najatrakcyjniejsze miejsca pótnocnej części Euroregionu Bug, Biała Podlaska 2005.

Kondracki J., Geografia regionalna Polski, Warszawa 2002.

Krukowska R., Skowronek E. Walory przyrodnicze jako podstawa rozwoju turystyki w gminie Włodawa, Sport i Turystyka, nr 1, 2009.

Radwan S., (red.): Poleski Park Narodowy. Monografia przyrodnicza, Lublin 2002.

Richling A., Solon J. Ekologia krajobrazu. PWN, Warszawa. 1996.

Wilgat T., Wody Lubelszczyzny, Lublin 1998.

Wojciechowski K., Krajobraz jako zwierciadto stylu życia (II), w: A. Anasiewicz, B. Chmiel, (red.): Roztoczańskie spotkania, t. I, Zwierzyniec. 2000.

Wojciechowski K., Europejska sieć ekologiczna Natura 2000 i Europejskie Korytarze Ekologiczne w: R. Horodeński, C. Sadowska-Snarska, (red.) Walory przyrodnicze jako czynnik rozwoju regionów wschodniej Polski, Białystok 2003.

\section{Tourist and recreational potential of the landscape of the West Polesie Summary}

Natural environment conditions have player an import ant role in the development of tourism in the Polesie region, which is located in the eastern part of Lubelskie Voivodeship. The region Polesie Zachodnie (Western) is main tourist attractions include lakes, the Bug River as well as the plant cover. Important elements of the plant cover include forests: Włodawskie and Sobiborskie Forests. Because of the natural environment assets recreational complex of Bialskie, Białe, Glinki, Krasne, Piaseczno, Rogoźno and Zagłębocze lakes. Concurrently to the recreational tourism, specialist tourism is also developing. A lot importance is attache to agritourism. Authorities pay a lot of attention to proper use of natural environment assets. Assuming suitable level of investment, the Polesie stands a chance to become one of the most attractive regions of the eastern Poland Area. Strategic aim of Polesie Zachodnie is protection of natural valuesand their use for economic development and enrichment of local community.

Translated by: Joanna Kurczyńska 